\title{
LUMINESCENCE DATING OF NEOLITHIC CERAMICS FROM LUMEA NOUĂ, ROMANIA
}

\author{
VASILE BENEA ${ }^{1}$, DIMITRI VANDENBERGHE ${ }^{2, \text { a }}$, ALIDA TIMAR ${ }^{1}$, PETER VAN DEN HAUTE ${ }^{2}$, \\ CONSTANTIN COSMA ${ }^{1}$, MIHAI GLIGOR ${ }^{3}$ and CRISTIAN FLORESCU ${ }^{3}$ \\ ${ }^{I}$ Faculty of Environmental Science, Babes-Bolyai University, \\ Piata Stefan Cel Mare 4, RO-400192 Cluj-Napoca, Romania \\ ${ }^{2}$ Laboratory of Mineralogy and Petrology (Luminescence Research Group), Geological Institute (S8), Ghent University, \\ Krijgslaan 281, B-9000 Gent, Belgium \\ 3 "1 Decembrie 1918” University, Systemic Archaeology Institute, \\ Mihai Viteazul 12, RO-510010, Alba Iulia, Romania
}

Received 3 July 2007

Accepted 11 September 2007

\begin{abstract}
Luminescence dating was applied to four Neolithic pottery fragments excavated at Lumea Nouă (Alba Iulia, Romania), with the purpose of improving the chronology for the archaeological finds, and hence, the occupational history of the site. The single-aliquot regenerative-dose (SAR) protocol was applied to both blue and infrared stimulated luminescence signals from coarse quartz and polymineral fine grains, respectively. A more conventional approach which uses a multiple-aliquot additive-dose protocol and thermoluminescence signals from polymineral fine grains was applied as well.

The characteristics of the OSL and IRSL signals were investigated in terms of behaviour in the SAR protocol, dose response and dose recovery. Additionally, anomalous fading measurements of the 410 nm IRSL emission and of the blue TL emission from polymineral fine-grains were performed. Both signals were observed to be affected by anomalous fading. OSL dating of quartz using the SAR protocol is considered to be the technique of choice; it yields an average age of $6.0 \pm 0.4 \mathrm{ka}(\mathrm{n}=4)$, which is in agreement with archaeological expectations. The dating results allow refining the typological interpretation of the objects and improve the chronological framework for the site.
\end{abstract}

Keywords: optically stimulated luminescence, infrared stimulated luminescence, thermoluminescence, anomalous fading, Neolithic pottery.

\section{INTRODUCTION}

Pottery is often the most abundant material found on archaeological sites and is the basis of many chronological frameworks for the Neolithic, especially in Southeast Europe. Pottery sherds can be dated by four methods: stylistic features, archaeomagnetic intensity, ${ }^{14} \mathrm{C}$ assay of carbon on or within the sherd and luminescence analysis of the constituent mineral grains. The most important limitation of stylistic dating is that it can provide only a relative chronology, and it must therefore rely on associations in order for ages to be obtained. Archaeomagnetic intensity analysis is a promising method (McIntosh et al. 2006), but at the moment is not widely applied. Radio-

Corresponding author: A. Timar

e-mail: alida_timar@yahoo.com

ISSN 1897-1695 (online), 1733-8387 (print) (C 2007 GADAM Centre, Institute of Physics, Silesian University of Technology.

All rights reserved. carbon dating is a well-known and established method, but it requires suitable organic material and dates an event which does not always relate to the archaeological event of interest. Luminescence dating, on the other hand, has the two major advantages of being an absolute technique giving the age in calendar years and of being a technique that dates the ceramic object directly.

The possibility of dating ceramic objects by the use of their thermoluminescent properties was first proposed by Grogler et al. (1960) and Kennedy and Knopff (1960). Since then, the method has been extensively studied and applied (see e.g. the reviews by Aitken, 1985 and Roberts, 1997). In the last few years, there have been major developments in both luminescence dating instrumentation and measurement methodology. The introduction of optically stimulated luminescence (OSL) signals in com-

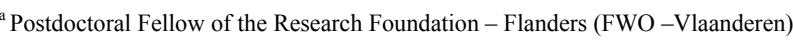


bination with single-aliquot measurement protocols has led to a significant increase in precision, while less sample material is required; this makes luminescence dating a potentially much more useful chronometric tool in archaeology. Nevertheless, the application of luminescence to burnt pottery appears to have benefited only little from these advances in dating technology. Only a few studies are available in the literature and some relevant reports include those by Hong et al. (2001), Takano et al. (2003) and Lamothe (2004). The latter author applied state-ofthe-art luminescence dating procedures (i.e. using the single-aliquot regenerative-dose (SAR) protocol, and both infrared and blue stimulated luminescence signals) to heated artefacts from archaeological sites in Quebec (Canada) and demonstrated that these procedures are able to provide a reliable chronological framework.

In this study, luminescence dating was applied to four pottery fragments excavated at Lumea Nouă (Alba Iulia, Romania). Although the Lumea Nouă settlement has been investigated for over 6 decades now, there is still no accurate and precise chronology available for the excavated Neo-Aeneolithic habitation levels. Therefore, the aim of this study was to investigate the potential of new approaches in optical dating for improving the chronological framework for the site. To this purpose, the singlealiquot regenerative-dose (SAR) protocol was applied to both blue (OSL) and infrared stimulated luminescence (IRSL) signals from coarse $(90-125 \mu \mathrm{m})$ quartz and polymineral fine $(4-11 \mu \mathrm{m})$ grains, respectively. For the sake of comparison, a more conventional approach, which uses a multiple-aliquot additive-dose (MAAD) protocol and thermoluminescence (TL) signals from polymineral fine grains, was applied as well.

\section{ARCHAEOLOGICAL CONTEXT AND SAM- PLES}

The prehistoric settlement at Lumea Nouă (Alba Iulia, Romania) was accidentally discovered in 1942 as a result of public utility works. The first archaeological campaigns were carried out between 1944 and 1947, and systematic excavations have been carried out since then. Although the site is considered to be of major importance for reconstructing the Neolithic and Aeneolithic periods in Romania, a solid and absolute chronological framework has not yet been established for the different cultural levels discovered at the settlement.

The site is located in the north-eastern part of the city of Alba Iulia (Alba County; Fig. 1), and has acquired an important place on the archaeological map of Romania, especially due to the identification of the painted pottery type that was later named after the settlement - Lumea Nouă.

At present, following the intensification of archaeological excavations and the setting out of research units at different points of the site, we know that the surface of the Neolithic settlement at Alba Iulia - Lumea Nouă exceeds 40 ha. The Neolithic and Aeneolithic habitations of the Lumea Nouă settlement belong - in chronological order - to Vinča, Lumea Nouă, Foeni, and Petreşti cultures. Recent investigations have led to the discovery of a habitation level that was attributed to the Foeni group, on

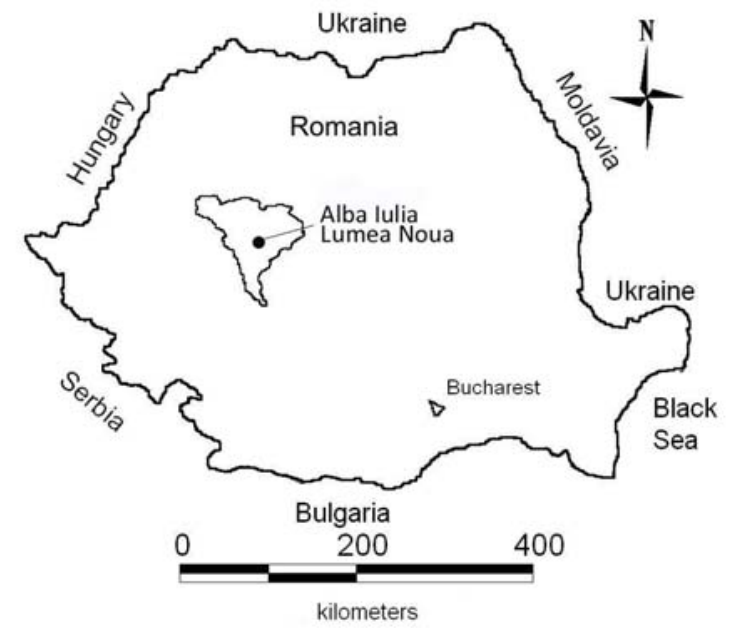

Fig. 1. Location of the archaeological site Lumea Nouă (Alba Iulia, Alba County, Central Romania).

the basis of the rich and representative archaeological material found there. Foeni-type pottery at Lumea Nouă depicts a community that is locally developing towards the Petreşti culture. It is thought that the site contains a wealth of information which could significantly improve our understanding of the genesis of the Petreşti culture (Gligor, 2006).

The stratigraphy of the sampling site (northern profile, square A) is the following (Fig. 2):

I: $0-0.5(0.7) \mathrm{m}$ : a blackish layer containing isolated materials in a secondary position. It is considered to be a filling layer, and is possibly a contemporary anthropogenic deposit;

II: $0.5(0.7)-0.8(0.9) \mathrm{m}$ : a black pigmented and granulated layer belonging to the Petreşti culture;

III: $0.8(0.9) \mathrm{m}-1.0(1.1) \mathrm{m}$ : a grey pigmented layer belonging to the Foeni group;

IV: $1.0(1.1) \mathrm{m}-1.7 \mathrm{~m}$ : a brownish and clayey layer containing Vinča materials (phase B) and Lumea Nouă painted pottery;

$\mathrm{V}: 1.7 \mathrm{~m}-1.8 \mathrm{~m}$ : a yellow pigmented layer. It is a

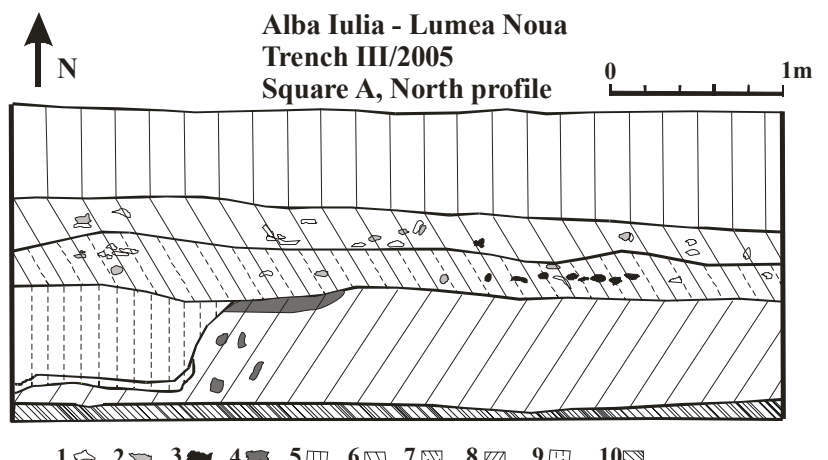

Fig. 2. Stratigraphy of the sampling site. 1 - pottery, 2 - bone, 3 - stone, 4 - calcareous formation, 5 - black layer of filling material, 6 - black granular layer belonging to the Petreşti culture, 7 - grey pigmented layer belonging to the Foeni group, 8 - brownish and clayey layer containing Vinča (phase B) materials, 9 - black and clayey layer containing Vinča (phase B) materials, 10 - archaeological sterile unit. 
clayey, sometimes sandy unit containing calcareous concretions and no artefacts.

The pottery sherds were collected from the cultural layer, at a depth of 0.8-0.9 m, thus from the superior part of layer III indicating the transition from Foeni group to Petreşti culture. The fragments were manufactured using medium sand as a degreasing agent, and thus the resulting pottery belongs to the medium-fine category. From a typological and stylistic point of view, the sherds lack diagnostic characteristics that would allow a precise cultural framing. The lack of ornamental elements is a minus in this respect.

\section{LUMINESCENCE ANALYSIS}

\section{Sample preparation}

All sample preparation was carried out under dim red or orange light conditions. The outer $2 \mathrm{~mm}$ of each pottery fragment was removed, and the inner part was gently crushed using an agate pestle and mortar. The material was then treated with $\mathrm{H}_{2} \mathrm{O}_{2}$ and $\mathrm{HCl}$ to remove organic material and carbonates, respectively, and was sieved using a $63 \mu \mathrm{m}$ sieve. Polymineral fine (4-11 $\mu \mathrm{m})$ grains were isolated from the fraction $<63 \mu \mathrm{m}$ using standard procedures (Zimmerman, 1971; Frechen et al., 1996). Aliquots of polymineral fine grains were prepared by deposition on aluminum discs. Coarse (90-125 $\mu \mathrm{m})$ grains were isolated through dry sieving. Quartz grains were extracted by density separation using sodium polytungstate solutions of 2.62 and $2.75 \mathrm{~g} \mathrm{~cm}^{-3}$, followed by etching for $40 \mathrm{~min}$ with $40 \% \mathrm{HF}$. A 60 min wash with warm $\left(\right.$ ca. $50^{\circ} \mathrm{C}$ ) dilute $\mathrm{HCl}$ was applied after etching to remove any precipitated fluorides. Finally, the extracts were dried and sieved again. For measurement, the quartz grains were fixed on stainless steel discs using silicon spray.

\section{Experimental facilities}

All luminescence measurements were carried out using automated Risø TL/OSL readers. The TL signals from polymineral fine grains were measured up to $500^{\circ} \mathrm{C}$ at a heating-rate of $5^{\circ} \mathrm{C} / \mathrm{s}$ in a pure nitrogen atmosphere. Emission light was detected through a heat absorbing HA-3 and a blue transmitting CN7-59 filter combination. Coarse quartz grains were stimulated using blue $(470 \pm 30 \mathrm{~nm})$ light-emitting diodes, and the OSL signals were detected through a $7.5 \mathrm{~mm}$ thick Hoya U-340 filter. Polymineral fine grains were stimulated with infrared $(875 \mathrm{~nm})$ light-emitting diodes. The IRSL signals were detected through a combination of a BG-39, CN7-59 and GG-400 filters $(410 \mathrm{~nm})$. Details on the measurement apparatus can be found in Bøtter-Jensen et al. (2003).

\section{TL measurements using polymineral fine grains}

The equivalent dose $\left(D_{e}\right)$ was determined using a standard TL multiple-aliquot additive-dose procedure. For each sample, 48 aliquots were used. All samples were stored for 4 weeks at room temperature between irradiation and measurement. A first set of 24 aliquots was used for the measurement of the natural TL signal. To build up the dose-response curve, a second set of 24 aliquots was used, divided in groups of six aliquots. The supralinearity correction was evaluated from the second-glow growth characteristic of the set of aliquots that provided the natural TL data. The equivalent dose was determined using the signals integrated over the plateau region in a plot of the apparent accumulated dose versus temperature (Aitken, 1985). A single saturating exponential was fitted to both the additive-dose and the second-glow growth data. The equivalent dose and the intercept, respectively, were then obtained by extrapolation. The TL glow curves obtained for sample A1 are illustrated in Fig. 3a along with the plateau test (Fig. 3b), and growth curve and second-glow growth characteristic for evaluation of the supralinearity correction (Fig. 3c).

The results of the equivalent dose determination using TL signals from polymineral fine grains are summarised in Table 1.

Table 1. Summary of equivalent doses $\left(D_{e}\right)$, calculated dose rates and ages. Uncertainties mentioned with the $D_{e}$ 's and dose rates are random and represent 1 sigma. The uncertainties on the ages were calculated following the error assessment system proposed by Aitken and Alldred (1972) and Aitken (1976).

\begin{tabular}{|c|c|c|c|c|c|c|c|c|c|c|c|}
\hline Sample & $\begin{array}{l}\text { Measurement } \\
\text { method }\end{array}$ & $\begin{array}{l}\text { Mineral } \\
\text { fraction }\end{array}$ & $\begin{array}{l}D_{e} \\
(G y)\end{array}$ & $\begin{array}{c}\text { Dose rate to } \\
90-125 \mu \mathrm{m} Q \\
\left(\mathrm{~Gy} \mathrm{ka}^{-1}\right)\end{array}$ & $\begin{array}{c}\text { Dose rate to } \\
\text { 4-11 } \mu \mathrm{m} \text { PFG } \\
\left(\mathrm{Gy} \mathrm{ka}^{-1}\right)\end{array}$ & $\begin{array}{l}\text { Uncor- } \\
\text { rected } \\
\text { age } \\
\text { (ka) }\end{array}$ & $\begin{array}{l}\text { Ran- } \\
\text { dom } \\
\text { uncer- } \\
\text { tainty } \\
(\%)\end{array}$ & $\begin{array}{l}\text { System- } \\
\text { atic un- } \\
\text { certainty } \\
(\%)\end{array}$ & $\begin{array}{l}\text { To } \\
\text { uncer } \\
(\%)\end{array}$ & $\begin{array}{l}\text { al } \\
\text { ainty } \\
\text { (ka) }\end{array}$ & $\begin{array}{c}\text { Corrected } \\
\text { age } \\
\text { (ka) }\end{array}$ \\
\hline \multirow{3}{*}{ A1 } & TL MAAD & 4-11 $\mu \mathrm{m}$ PFG & $19.2 \pm 1.2$ & \multirow{3}{*}{$3.14 \pm 0.02$} & \multirow{3}{*}{$4.36 \pm 0.02$} & $\overline{4.4}$ & 6.4 & 13.3 & 14.8 & 0.7 & \\
\hline & OSL SAR & $90-125 \mu \mathrm{m} Q$ & $20.0 \pm 0.8$ & & & 6.4 & 4.1 & 7.2 & 8.3 & 0.5 & \\
\hline & IRSL SAR & 4-11 $\mu \mathrm{m}$ PFG & $19.0 \pm 0.2$ & & & 4.4 & 1.0 & 13.3 & 13.3 & 0.6 & $6.4 \pm 0.9$ \\
\hline \multirow{3}{*}{ V1 } & TL MAAD & 4-11 $\mu \mathrm{m}$ PFG & $20.1 \pm 2.6$ & \multirow{3}{*}{$3.09 \pm 0.03$} & \multirow{3}{*}{$4.29 \pm 0.02$} & 4.7 & 13.0 & 13.9 & 19.0 & 0.9 & \\
\hline & OSL SAR & $90-125 \mu \mathrm{m} Q$ & $16.8 \pm 0.5$ & & & 5.5 & 2.9 & 7.8 & 8.3 & 0.5 & \\
\hline & IRSL SAR & 4-11 $\mu \mathrm{m}$ PFG & $21.8 \pm 0.4$ & & & 5.1 & 2.0 & 13.4 & 13.5 & 0.7 & $6.6 \pm 0.9$ \\
\hline \multirow{3}{*}{ V2 } & TL MAAD & 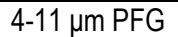 & $27.1 \pm 4.0$ & \multirow{3}{*}{$2.87 \pm 0.03$} & \multirow{3}{*}{$3.95 \pm 0.02$} & 6.9 & 14.8 & 13.1 & 19.8 & 1.4 & \\
\hline & OSL SAR & $90-125 \mu \mathrm{m} Q$ & $14.7 \pm 0.2$ & & & 5.1 & 1.9 & 6.9 & 7.2 & 0.4 & \\
\hline & IRSL SAR & 4-11 $\mu \mathrm{m}$ PFG & $18.4 \pm 0.7$ & & & 4.7 & 3.6 & 13.1 & 13.6 & 0.6 & $6.3 \pm 0.9$ \\
\hline \multirow{3}{*}{ V3 } & TL MAAD & 4-11 $\mu \mathrm{m}$ PFG & $24.1 \pm 2.5$ & \multirow{3}{*}{$2.81 \pm 0.02$} & \multirow{3}{*}{$4.06 \pm 0.02$} & 5.9 & 10.3 & 14.6 & 17.9 & 1.1 & \\
\hline & OSL SAR & $90-125 \mu \mathrm{m} Q$ & $20.2 \pm 0.6$ & & & 7.2 & 3.2 & 7.2 & 7.9 & 0.6 & \\
\hline & IRSL SAR & 4-11 $\mu \mathrm{m}$ PFG & $23.6 \pm 0.8$ & & & 5.8 & 3.2 & 14.9 & 15.2 & 0.9 & $7.7 \pm 1.2$ \\
\hline
\end{tabular}




\section{OSL measurements using coarse quartz grains}

Coarse quartz grains were stimulated with the blue diodes for $40 \mathrm{~s}$ at $125^{\circ} \mathrm{C}$ and a single-aliquot regenerativedose (SAR) protocol (Murray and Wintle, 2000; 2003) was used for equivalent dose determination. The characteristics of the OSL signals were first investigated in terms of behavior in the SAR protocol, dose response and dose recovery. All samples behaved well in the SAR-
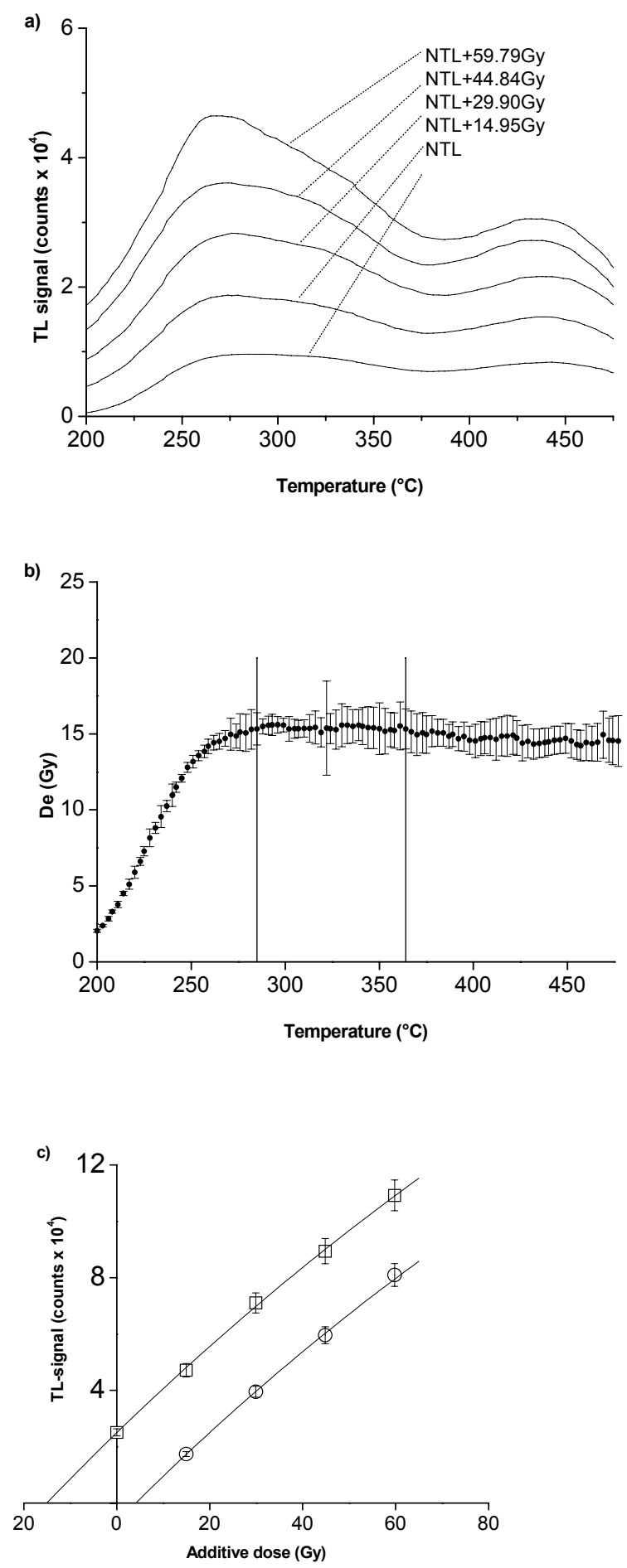

Fig. 3. $T L$ data for sample A1; (a) $T L$ additive glow curves, (b) plateau range, and (c) additive growth curve (solid squares) and second-glow growth characteristic (solid circles).
OSL protocol, with recycling ratios close to unity and recuperation of less than a few $\%$ of the corrected natural OSL signal. The growth of the OSL signals with dose could be well-approximated by a single saturating exponential function. Fig. 4 represents a growth curve for sample V1. For sample V3 the dependence of the measured dose on the preheat temperature was investigated through dose recovery tests (Murray and Wintle, 2003). Aliquots were first bleached twice using the blue diodes for $250 \mathrm{~s}$ at room temperature, separated by a $10 \mathrm{ks}$ pause. They were then given a dose close to the expected natural dose, and measured using the SAR protocol. The results are shown in Fig. 5. It can be seen that the measured dose underestimates the given dose for preheats in the range of $180-225^{\circ} \mathrm{C}$. For a preheat of $10 \mathrm{~s} @ 240^{\circ} \mathrm{C}$, a measured to given dose ratio of $1.10 \pm 0.08$ was obtained, which is quite acceptable. In a following series of experiments,

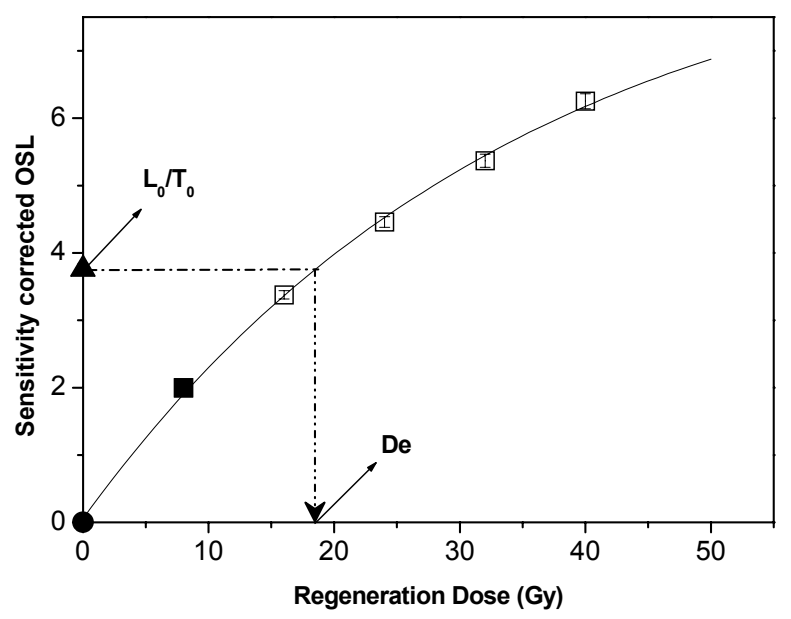

Fig. 4. Sensitivity corrected OSL growth curve for sample V1. Data points were fitted using a saturating exponential. Zero dose and recycling points are represented as a solid circle and solid square, respectively.

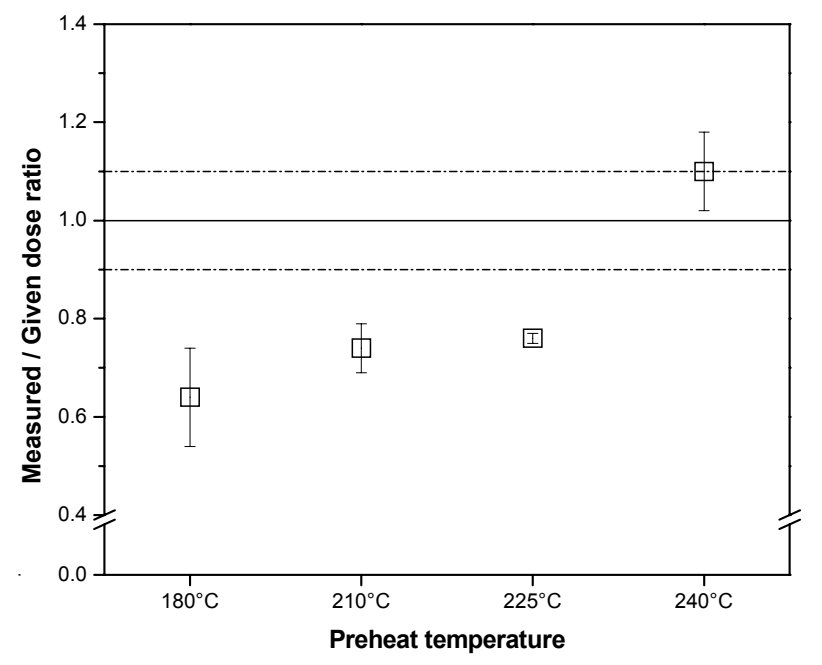

Fig. 5. Quartz SAR-OSL dose recovery data for sample V3 as measured to given dose ratios as a function of preheat treatment. The solid and dashed lines (eye guides) represent a measured to given dose ratio equal to unity and a $10 \%$ deviation of this ratio from unity, respectively. 
dose recovery tests were carried out for samples A1, V1 and V2 as well. Owing to the limited amount of sample available, these tests were carried out for a preheat of $10 \mathrm{~s}$ at $240^{\circ} \mathrm{C}$ only. The complete sets of results obtained for this preheat are summarized in Fig. 6a and Fig. 6b. For all samples, the given doses can be recovered to within $10 \%$ and the overall average measured to given dose ratio is $1.03 \pm 0.04$. From these findings, a preheat of $10 \mathrm{~s}$ at $240^{\circ} \mathrm{C}$ was selected for determining the equivalent dose using OSL signals from quartz and the SAR protocol. A cutheat of $160^{\circ} \mathrm{C}$ was used in all experiments. The results of the $D_{e}$ determination are summarized in Table 1 .

\section{IRSL measurements using polymineral fine grains}

Polymineral fine grains aliquots were stimulated using the IR diodes for $100 \mathrm{~s}$ at $40^{\circ} \mathrm{C}$, and the measurements were performed following a SAR sequence as developed for quartz. The same preheat was applied to both the regenerative and test doses as this enhances the reproducibility of the luminescence measurements (Blair et al., 2005). All samples behaved well in the SAR-IRSL protocol, with recycling ratios close to unity and recuperation values not exceeding a few $\%$ of the corrected natural
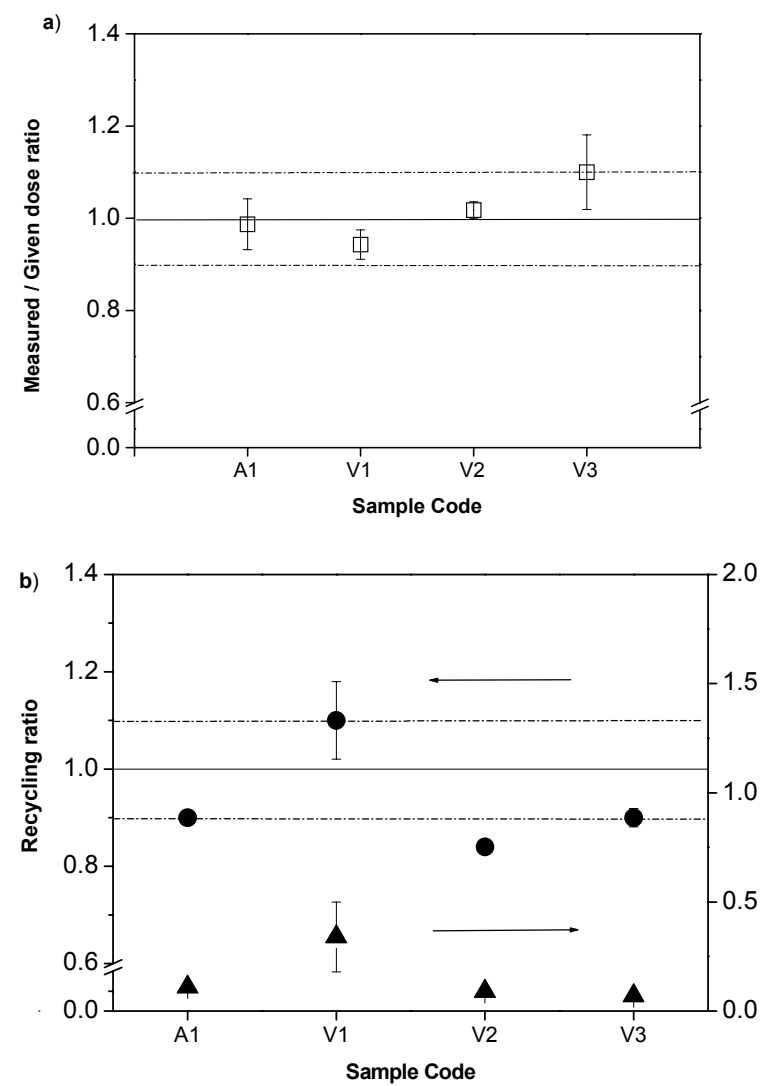

Fig. 6. (a) Summary of quartz SAR-OSL dose recovery data obtained for all for samples using a preheat of $10 \mathrm{~s}$ at $240^{\circ} \mathrm{C}$ and a cut heat to $160^{\circ} \mathrm{C}$. The solid and dashed lines (eye guides) represent a measured to given dose ratio equal to unity and a $10 \%$ deviation of this ratio from unity, respectively (b) recycling ratios and recuperation. The solid and dashed lines (eye guides) represent a recycling ratio equal to unity and a $10 \%$ deviation from unity, respectively. Error bars represent 1 standard error.
IRSL signal. The growth of the sensitivity corrected IRSL signal with dose could be well represented by a single saturating exponential function. A representative growth curve for sample A1 is illustrated in Fig. 7. The first series of experiments consisted of an investigation of dependency of the recovered dose on the stringency of the preheat. These experiments were carried out for sample A1. Groups of aliquots were first bleached for 1 hour in a Hönle SOL 2 solar simulator, and were subsequently given a dose close to the expected natural dose. The aliquots were then measured using the SAR protocol, with each group being preheated for a different length of time at $220^{\circ} \mathrm{C}(10 \mathrm{~s}, 30 \mathrm{~s}$ and $60 \mathrm{~s})$. The results are shown in Fig. 8. The measured dose shows no dependence on preheat regime and approximates the given dose rather well. For the remaining three samples, dose recovery tests were carried out for a preheat of $10 \mathrm{~s}$ at $220^{\circ} \mathrm{C}$ only. The dose recovery results for all samples at this preheat are summarized in Fig. 9a. Within analytical uncertainty, the

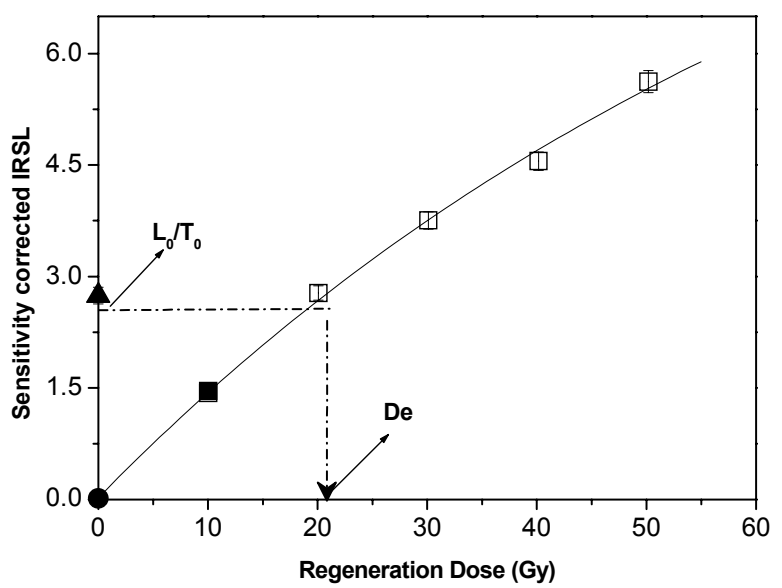

Fig. 7. Sensitivity corrected IRSL growth curve for sample A1. Data points were fitted using a saturating exponential. Zero dose and recycling points are represented as a solid circle and solid square, respectively.

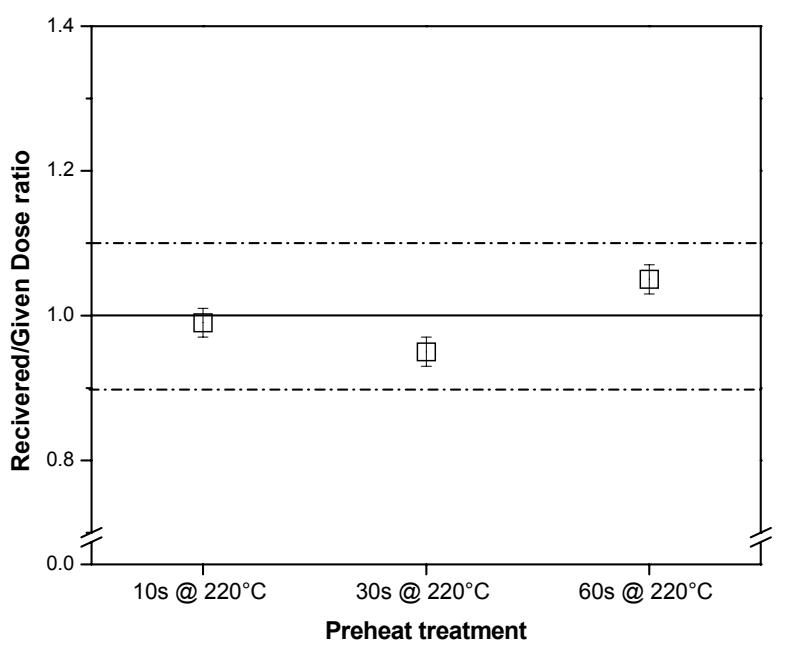

Fig. 8. SAR-IRSL dose recovery data for polymineral fine grains extracted from sample $A 1$ as function of preheat treatment. 
measured to given dose ratios are all consistent with unity. The overall average measured to given dose ratio obtained with the SAR-IRSL protocol is $1.01 \pm 0.02$. Fig. 9b shows the corresponding recycling ratios and recuperation values; the overall averages for recycling ratio and recuperation are $1.06 \pm 0.02$ and $1.9 \pm 0.6 \%$, respectively.

A preheat treatment of $10 \mathrm{~s}$ at $220^{\circ} \mathrm{C}$ for both regenerative and test doses was selected for $\mathrm{D}_{\mathrm{e}}$ determination; the results are summarised in Table $\mathbf{1 .}$

\section{Anomalous fading tests}

For each sample, anomalous fading measurements of the blue TL emission (detected through a HA-3 and CN7-59 filter combination) and of the $410 \mathrm{~nm}$ IRSL emission (detected through a BG39, CN7-59 and GG400 filter combination) by polymineral fine-grains were carried out.

In the case of TL measurements, for each sample a group of six natural aliquots was irradiated with the highest beta dose that had been administrated to construct the additive dose growth curve. Signals measured immediately after irradiation were compared to the signals measured after storage (first glow test - Aitken 1985, p. 58). The time elapsed between the prompt and the delayed measurement was one month.

For IRSL signals, the anomalous fading tests were
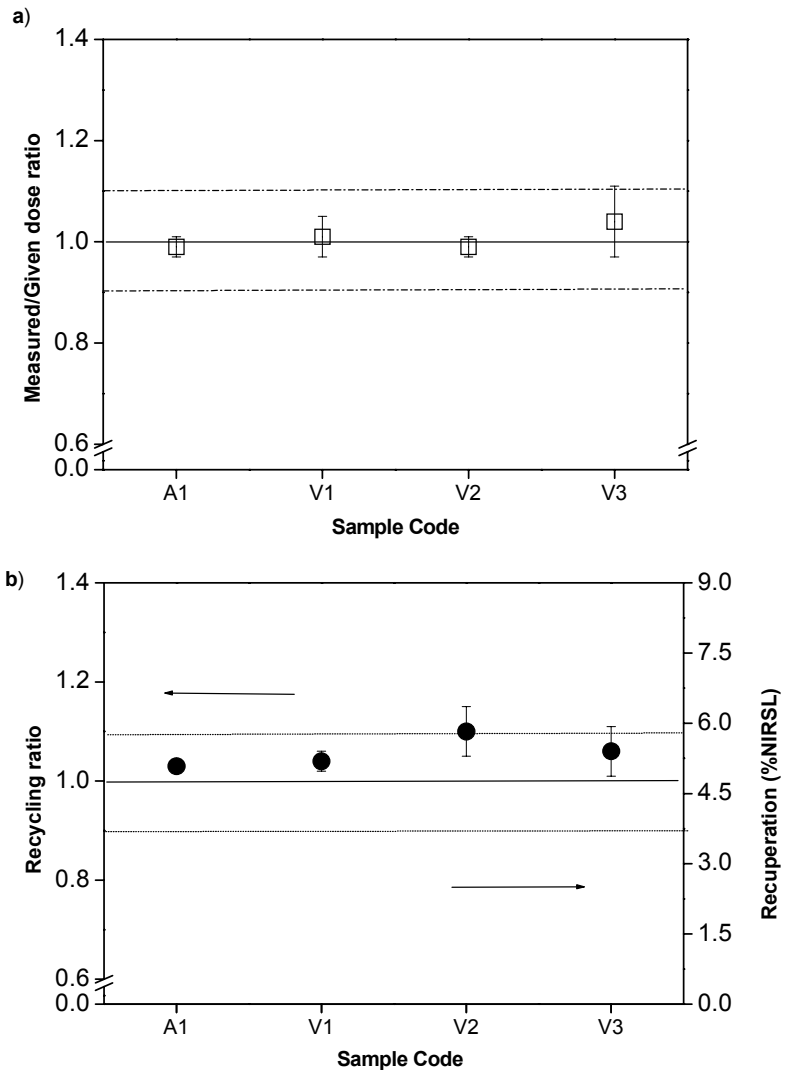

Fig. 9. SAR-IRSL dose recovery data for all investigated samples using polymineral fine grains. The thermal treatments consisted of $10 \mathrm{~s}$ preheat at $220^{\circ} \mathrm{C}$ and cut heat to $220^{\circ} \mathrm{C}$. (a) measured to given dose ratios; (b) recycling ratio and recuperation. Error bars represent 1 standard error. carried out in a SAR protocol following the procedure proposed by Auclair et al. (2003). For each sample, three aliquots were bleached for one hour in the Hönle SOL2 solar simulator after these had been used for $\mathrm{D}_{\mathrm{e}}$ determination. These aliquots were then put through repeated cycles of measuring the response to a regenerative dose $\left(\mathrm{L}_{\mathrm{i}}\right)$ and a test dose $\left(\mathrm{T}_{\mathrm{i}}\right)$. Prompt measurements were made, for which the $L_{i} / T_{i}$ ratio was measured immediately after irradiation, as well as delayed measurements, for which the $\mathrm{L}_{\mathrm{i}} / \mathrm{T}_{\mathrm{i}}$ ratio was measured after the aliquots had been stored at room temperature for different lengths of time after irradiation and preheating. Each delayed measurement was followed by a prompt measurement, in order to enable distinguishing the true signal loss caused by fading from experimental variability in the measurements. The $\mathrm{L}_{\mathrm{i}}$ and $\mathrm{T}_{\mathrm{i}}$ measurement conditions were the same as for the equivalent dose determinations. For each aliquot, the fading rate was then obtained from a plot of the $L_{i} / T_{i}$ ratios versus the logarithm of the time elapsed between irradiation and measurement. All fading rates were quantified as $g_{2 \text { days }}$-values (the percentage decrease of intensity per decade of time, normalised to a measurement time of 2 days after irradiation; Aitken, 1985; Huntley and Lamothe, 2001). Anomalous fading was observed in every aliquot examined. Fig. 10 shows representative anomalous fading data for an aliquot of sample A1. Mean values of $\mathrm{g}_{2 \text { days }}$ are summarised in Table 2 together with the percentage signal loss for thermoluminescence measurements. The amount of fading observed in IRSL signal is similar in all the samples investigated. In the case of TL, the first three samples exhibit comparable signal loss. No fading was observed in the last sample but this could be due to the poor reproducibility of the TL measurements for this sample.

\section{ANNUAL DOSE DETERMINATION}

The concentration of uranium and thorium in the ce-

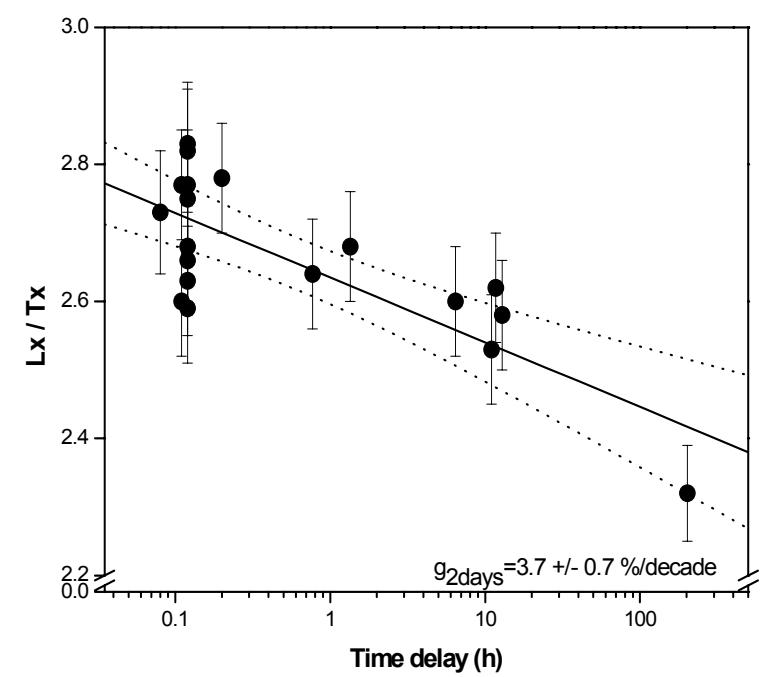

Fig. 10. Anomalous fading data for a representative aliquot of sample A1. Plotted are the measured $L_{i} / T_{i}$ ratios versus the logarithm of the time elapsed since the end of the irradiation. A linear dependency can be noticed. Dotted lines indicate upper and lower $95 \%$ confidence levels. 
Table 2. Results from anomalous fading tests. In the case of TL measurements, the fading is expressed as the percentage of signal loss observed after a storage time of one month. In the case of IRSL meas-

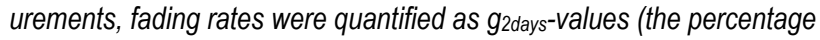
decrease of intensity per decade of time, normalised to a measurement time of 2 days after irradiation; Aitken, 1985; Huntley and Lamothe, 2001).

\begin{tabular}{ccc}
\hline Sample & $\begin{array}{c}\text { signal loss }(\%) \\
\text { TL }\end{array}$ & $\begin{array}{c}\mathbf{g}_{2 \text { days }}(\% \text { per decade }) \\
\text { IRSL }\end{array}$ \\
\hline A1 & $9.4 \pm 3.3$ & $4.2 \pm 0.2$ \\
V1 & $11.8 \pm 2.7$ & $2.98 \pm 0.40$ \\
V2 & $16.0 \pm 3.6$ & $3.63 \pm 1.06$ \\
V3 & $-1.1 \pm 7.6$ & $3.33 \pm 1.03$ \\
\hline
\end{tabular}

ramics was obtained through instrumental neutron activation analysis using the zirconium standardisation method (De Corte 1987), while the $\mathrm{K}$ content was determined using atomic absorption spectrometry. Low-background high-resolution gamma-ray spectrometry provided the dosimetric information for the surrounding soil (Hossain et al., 2002; Vandenberghe, 2004).

Concentrations were converted into annual doses using the conversion factors given by Adamiec and Aitken (1998). The contribution of cosmic rays to the dose rate was calculated following Prescott and Hutton (1994). For the polymineral fine grains, an a-value of $0.10 \pm 0.05$ was used to allow for the lower efficiency of alpha radiation in inducing luminescence. For the calculation of the beta dose rate to $90-125 \mu \mathrm{m}$ quartz grains, a beta attenuation factor of $0.92 \pm 0.05$ was adopted, based on the calculations by Mejdahl (1979). The saturation content (W-value; Aitken, 1985) of all pottery sherds was determined in the laboratory; the sherds were assumed to have been in saturation for $80 \%$ of the time. Table 3 summarises all the dosimetric information.

\section{LUMINESCENCE AGES AND DISCUSSION}

The presence of anomalous fading in the $410 \mathrm{~nm}$ IRSL emission as well as blue TL emission indicates that our IRSL and TL ages would underestimate the true ages. To correct the SAR-IRSL results for fading, we applied correction procedure proposed by Huntley and Lamothe (2001). No correction was applied to the TL results, as it remains to be established whether it is valid to correct the bulk signal originating from an undifferentiated finegrained mineral mixture using the fading observed from only part of this mixture. The TL, SAR-OSL and SARIRSL ages (both corrected and uncorrected) are presented in Table 1; for the sake of visualisation, they are also plotted in Fig. 11.

In general, the uncorrected TL-ages are consistent with the uncorrected SAR-IRSL ages, and both are lower than the quartz SAR-OSL ages. The uncorrected TL age for sample V2 is higher than the uncorrected SAR-IRSL age, but this might be due to a lack in measurement precision. The fading corrected SAR-IRSL ages are in good agreement with the SAR-OSL ages.

Compared to the TL method, the IRSL and OSL approaches are based on a more robust dating methodology. Therefore, they are expected to yield the most reliable
Table 3. Elemental concentrations of natural radioactive nuclides in the ceramic sherds and surrounding soil, and estimates of past water content.

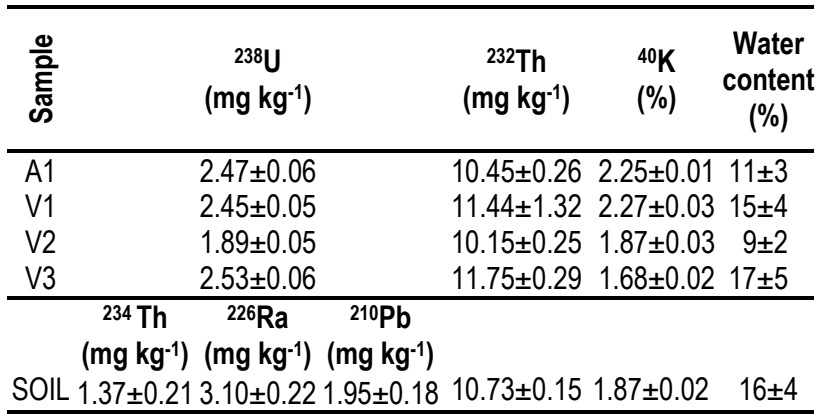

age information. Quartz has advantages with regard to dosimetry and anomalous fading and it yields the most precise age estimates; therefore, SAR-OSL dating of quartz is considered to be the technique of choice.

As mentioned before, there is no age control for Lumea Nouă site. The only possibility to evaluate the accuracy of our dates is by comparing them to age information that is available from other archaeological sites in Romania. Based on radiocarbon dating, Draşovean (2005) places the Foeni culture between $4798 \pm 122$ and $4520 \pm 60$ cal BC. For the beginning of the Petreşti culture (phase A), the ${ }^{14} \mathrm{C}$ data obtained for the settlement at Daia Română - Părăut give us the interval $3855 \pm 95$ cal BC (Paul, 1992). The average of the four quartz SAR-OSL ages presented above would place the transition from Foeni to Petreşti culture at Lumea Nouă site around $6.0 \pm 0.4 \mathrm{ka}$; taking into consideration the archaeological information, this age seems extremely plausible.

Further investigations are needed for establishing a complete chronological framework for the ancient cultural development at Lumea Nouă. Nevertheless the present study clearly illustrates how luminescence dating, especially by the use of state-of-the-art techniques can contribute to this purpose.

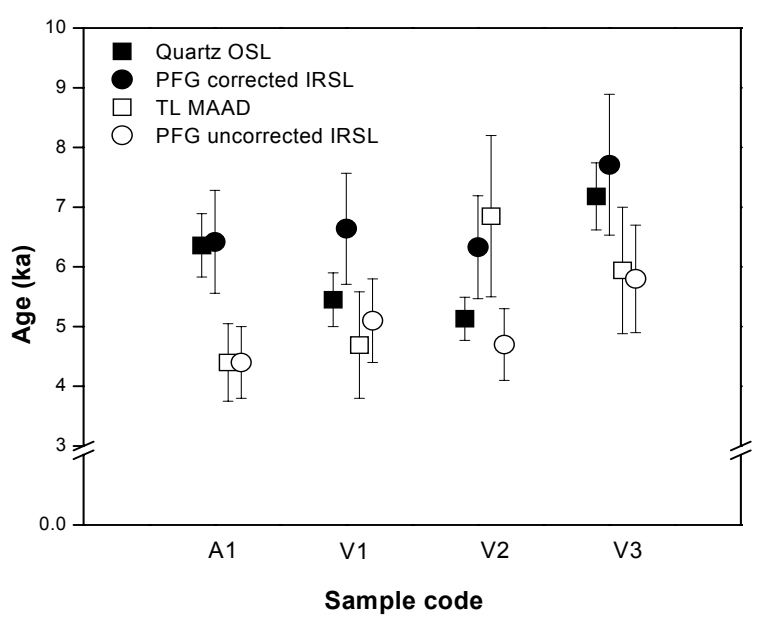

Fig. 11. Illustrative comparison of the ages obtained through the methods used. 


\section{ACKNOWLEDGEMENTS}

Sincere thanks are given to Dr. Barbos Dumitru for carrying out the neutron activation analysis for the ceramic samples at TRIGA Reactor, Nuclear Research Institute, Pitesti, Romania. The assistance of Nicole Selen during sample preparation is highly appreciated. Thanks are due to Sebastien Huot and Jan Pieter Buylaert for support and suggestions concerning anomalous fading measurements. This research was financed through Erasmus student grants (VB and AT) and the Fund for Scientific Research - Flanders (FWO - Vlaanderen; DV).

\section{REFERENCES}

Adamiec G and Aitken M, 1998. Dose-rate conversion factors: update. Ancient TL 16:37-50.

Aitken MJ, 1985. Thermoluminescence Dating. London. Academic Press, ISBN: 0-12-046380-6: 359pp.

Aitken MJ, 1976. Thermoluminescent age evaluation and assessment of error limits: revised system. Archaeometry 18(2): 233-238, DOI 10.1111/j.1475-4754.1976.tb00168.x.

Aitken MJ and Alldred JC, 1972. The assessment of error limits in thermoluminescent dating. Archaeometry 14(2): 257-267, DOI 10.1111/j.1475-4754.1972.tb00068.x.

Auclair M, Lamothe M and Huot S, 2003. Measurement of anomalous fading for feldspars IRSL using SAR. Radiation Measurements 37(4-5): 487-492, DOI 10.1016/S1350-4487(03)00018-0.

Blair MV, Yukihara EG and McKeever SWS, 2005. Experiences with single aliquot OSL procedures using coarse-grain feldspars. Radiation Measurements 39(4): 361-374, DOI 10.1016/j.radmeas.2004.05.008.

Bøtter-Jensen L, Andersen CE, Duller GAT and Murray AS, 2003. Developments in radiation, stimulation and observation facilities in luminescence measurements. Radiation Measurements 37(4-5): 535-541, DOI 10.1016/S1350-4487(03)00020-9.

De Corte F, 1987. The $k_{0}$ standardization method: A move to the optimization of neutron activation analysis. Rijksuniversiteit Report to Aggregate Thesis, Ghent University, 464pp.

Draşovean F, 2005. Zona thessalo-macedoneană şi Dunărea mijlocie la sfârşitul mileniului al VI-lea şi la începutul mileniului al V-lea A.CHR. (Thessalo Macedonian and Danube region at the end of sixth millennium, beginning of fifth millennium BC). Apulum XLII: 12-26 (in Romanian).

Frechen M, Schweitzer U and Zander A, 1996. Improvements in sample preparation for the fine grain technique. Ancient TL 14: 15-17.

Gligor M, 2006. Considerații privitoare la neoliticul târziu/eneoliticul timpuriu din S-V Transilvaniei. Materiale ceramice de la Alba Iulia-Lumea Nouă. (Considerations regarding late Neolithic/ Early
Aeneolithic in S-V of Transylvania. Ceramic materials discovered at Alba Iulia- Lumea Noua). Apulum XLIII(1): 9-34 (in Romanian).

Grogler N, Houtermans FG and Stauffer H, 1960. Ueber die Datierung von Keramik und Ziegel durch Thermolumineszenz. Helvetica Physica Acta 33: 595-596.

Hong DG, Yi SB, Galloway RB and Tsuboi T, 2001. Optical dating of archaeological samples using a single aliquot of quartz stimulated by blue light. Journal of Radioanalytical and Nuclear Chemistry 247(1): 179-184, DOI 10.1023/A:1006704207173.

Hossain SM, De Corte F, Vandenberge D and Van den Haute P, 2002. A comparison of methods for annual radiation dose determination in the luminescence dating of loess sediments. Nuclear Instruments and Methods in Physics Research A 490(3): 598-613, DOI 10.1016/S0168-9002(02)01078-1.

Huntley DJ and Lamothe M, 2001. Ubiquity of anomalous fading in Kfeldspars and the measurement and correction for it in optical dating. Canadian Journal of Earth Science 38: 1093-1106.

Kennedy GC and Knopff L, 1960. Dating by thermoluminescence. Archaeology 13: 147-148.

Lamothe M, 2004. Optical dating of pottery, burnt stones, and sediments from selected Quebec archaeological sites. Canadian Journal of Earth Sciences 41: 659-667.

McIntosh G and Catanzariti G, 2006. An introduction to archaeomagnetic dating. Geochronometria 25: 11-18.

Mejdahl V, 1979.Thermoluminescence dating: beta dose attenuation in quartz grains. Archaeometry 21(1): 61-72, DOI 10.1111/j.14754754.1979.tb00241.x

Murray AS and Wintle AG, 2000. Luminescence dating using an improved single-aliquot regenerative-dose protocol. Radiation Measurements 32(1): 57-73, DOI 10.1016/S1350-4487(99)00253-X.

Murray AS and Wintle AG, 2003. The single aliquot regenerative dose protocol: potential for improvements in reliability. Radiation Measurements 37(4-5): 377-381, DOI 10.1016/S13504487(03)00053-2.

Paul I, 1992. Cultura Petreşti (Petresti Culture). Bucureşti, Museion Publishing House (in Romanian), 205 pp.

Prescott JR and Hutton JT, 1994. Cosmic ray contributions to dose rates for luminescence and ESR dating: large depths and long-term time variations. Radiation Measurements 23(2-3): 497-500, DOI 10.1016/1350-4487(94)90086-8.

Roberts RG, 1997. Luminescence dating in archaeology: from origins to optical. Radiation Measurements 27(5-6): 819-892, DOI 10.1016/S1350-4487(97)00221-7.

Takano M, Yawata T and Hahimoto T, 2003. Luminescence dosimetry of archaeological and ceramic samples using a single- aliquot regenerative dose method. Journal of Radioanalytical and Nuclear Chemistry 255(2): 365-368, DOI 10.1023/A:1022521224134.

Vandenberghe D, 2004. Investigation of the optically stimulated luminescence dating method for application to young geological sediments. PhD thesis, Ghent University: 358pp.

Zimmerman DW, 1971. Thermoluminescence dating using fine grains from pottery. Archaeometry 13(1): 29-52, DOI 10.1111/j.14754754.1971.tb00028.x. 